\title{
Biodiversity of segetal weed community in continuous potato cultivated with metribuzin-based weed control
}

\author{
Zbigniew Pawlonka*, Katarzyna Rymuza, Krzysztof Starczewski, Antoni Bombik
}

Siedlce University of Natural Sciences and Humanities

Prusa 14, Siedlce 08-110, Poland

Received: May 14, 2014

Accepted: February 6, 2015

\begin{abstract}
The objective of the work reported here was to determine the relationship between herbicide rate and the biodiversity of weed communities in potato cultivated in continuous cropping. A seven-year field experiment was conducted to examine the effect of 4 metribuzin rates and an uncontrol on weed infestation in successive years of continuous potato cultivation. The following indices were calculated: the Shannon-Wiener and Simpson's indices of species diversity and the Simpson's index of domination. A total of 33 species were recorded in the experimental plots. Echinochoa crus-galli was the dominant species. The most abundant segetal communities were observed in untreated plots. An application of the herbicide reduced the biodiversity of the agrophytocenosis. Cultivation in continuous cropping increased the species number of the weed community in potato. The herbicide and cultivation in continuous cropping did not significantly affect the biodiversity indices but their values, to a great extent, confirmed the trends revealed by the analysis of weed infestation.
\end{abstract}

Key words: biodiversity, domination, potato, weeds

\section{Introduction}

The issue of agroecosystem biodiversity has been raised more and more often in agricultural research articles (Jastrzębska et al. 2007). Biological diversity refers to species abundance. Species abundance means species number and relative share per given area or typologic unit of a higher order (Wilson 1988). Field phytocenosis, consisting of the crop plant and companion weeds, is the most important component of agrobiocenosis (Jastrzębska et al. 2007). A harmful impact of weeds is an interaction of their number and reciprocal quantitative relations; this particularly refers to the dominating species. A weed community composed of several species can be and often is more harmful than a more diversified community (Anyszka and Kohut 2011). In recent years, ecological indices of species diversity and domination have been used in studies on weed infestation of cropped fields (Shannon 1948; Simpson 1949; Stupnicka-Rodzynkiewicz et al. 2004; Skrzyczyńska and Ługowska 2008; Rzymowska et al. 2013; Ługowska and Rzymowska 2014).

Many authors (Adamiak and Adamiak 2004; Kwiatkowski 2009) have suggested that cultivation of crop plants in a monoculture increases weed infestation and compensation of a few of the most expansive species, which suggests that the biodiversity of the segetal community declines. An application of herbicides is believed to be a factor causing floristic impoverishment of agrophytocenoses (Rychcik 2006). The objective of the work was to test these hypotheses by determining the biodiver- sity of segetal weed communities establishing in continuous potato with weed control based on an application of different metribuzin rates.

\section{Materials and Methods}

A field experiment was carried out on a private agricultural holding, in Wólka Leśna near Siedlce, from 2003 to 2009. It was set up on grey brown podzolic soil and arranged in a randomised block design with four replicates. The area of each plot was $2 \cdot 8 \mathrm{~m}$. Table potato cv. Cykada was cultivated in continuous cropping at the between-row spacing of $62.5 \times 25 \mathrm{~cm}$. Fertilisation rates of $80 \mathrm{~kg} \mathrm{~N}, 70$ $\mathrm{kg} \mathrm{P}_{2} \mathrm{O}_{5}$, and $90 \mathrm{~kg} \mathrm{~K} \mathrm{O}_{2} \mathrm{O}$ per ha were applied pre-planting. Potato blight and Colorado potato beetle were chemically controlled. We examined the effect of the metribuzin rates on the biodiversity of weed communities which had been establishing each year that there was continuous potato cultivation. Weeds were mechanically controlled from potato planting to germination. Metribuzin (Sencor $70 \mathrm{WG)}$ was applied prior to germination at the following rates:

1) the control treatment - no herbicide,

2) $0.5 \mathrm{~kg} \cdot \mathrm{ha}^{-1}$,

3) $1.0 \mathrm{~kg} \cdot \mathrm{ha}^{-1}$,

4) $1.5 \mathrm{~kg} \cdot \mathrm{ha}^{-1}$,

5) $2.25 \mathrm{~kg} \cdot \mathrm{ha}^{-1}$.

Weed infestation was examined at the stage of optimum development of weed communities in August (po- 
tato development stage $\mathrm{BBCH} 80-89)$. All the weeds within the area of $0.5 \mathrm{~m}^{2}$ were counted in four places of a plot. The results were averaged and expressed on a per $1 \mathrm{~m}^{2}$ basis. Moreover, the total numbers of species on all the plots and in each study year were calculated. The average number of weedy species per one plot was calculated for each herbicide rate and study year. Assessment of biodiversity was performed based on the species composition of weed communities and weed density of individual species, using the following indices:

1) Shannon-Wiener index of species diversity $-H^{\prime}$ (Shannon 1948):

$$
H^{\prime}=-\sum\left(p_{\mathrm{i}} \ln p_{\mathrm{i}}\right)
$$

2) Simpson's index of species diversity - C (Simpson 1949):

$$
C=1-\sum p_{\mathrm{i}}^{2}
$$

3) Simpson's index of domination - D (Simpson 1949):

$$
D=\sum p_{i}^{2}
$$

where: $p_{\mathrm{i}}$ - the share of $\mathrm{i}$-th species in the sample.

The above-mentioned indices are widely used in studies of biocenosis diversity. Species nomenclature follows Mirek et al. (2002). They were analysed by means of twofactor variance analysis with metribuzin rates and years as main effects. Comparison of means was obtained using Tukey's test at the probability level of $\mathrm{p} \leq 0.05$ (Trętowski and Wójcik 1992). All the calculations were performed with the use of Statistica 9.0.

\section{Results}

A total of 33 weedy species were found in all the experimental plots during the seven study years. Weed flora communities in potato establishing themselves at various herbicide rates were found to be from 16 to 24 taxons, and their average species numbers ranged from 3.3 to 5.6. The most abundant phytocenoses were observed in the untreated plots. When chemical control was applied, the total species richness was lower. The average species richness was significantly the lowest at the metribuzin rate of $1.5 \mathrm{~kg} \cdot \mathrm{ha}^{-1}$. The total weed density ranged from 28.1 plants $\cdot \mathrm{m}^{-2}$ at the highest rate, to 87.4 plants $\cdot \mathrm{m}^{-2}$ which was recorded in untreated plots (Table 1).

The length of the continuous potato cultivation period in the control plots (no herbicide) had little effect on the number of species in an agrocenosis. The average number of species was the lowest in the second and fourth study year and the highest in the fifth study year. The total number of species was the lowest in the first, fourth, and seventh study year and the highest in the fifth study year. The total number of weeds clearly increased in the third study year and the seventh study year (Table 2).

Echinochloa crus-galli was the dominant species over the seven-year study period but the species' abundance varied from year to year. An average number of E. crus- -galli plants significantly increased in the third and seventh study year. Metribuzin application at increased rates (1.5 and $2.25 \mathrm{~kg} \cdot \mathrm{ha}^{-1}$ ) significantly reduced the analysed characteristic, when compared with the control (Table 3).

The indices of biodiversity indicate that species composition of weed communities were only slightly affected by the metribuzin rates. The greatest biodiversity of the agrophytocenosis was observed in plots treated with the highest metribuzin rate, and in untreated plots. The lowest biodiversity and the highest index of domination were recorded in the plots treated with the $0.5 \mathrm{~kg} \cdot \mathrm{ha}^{-1}$ rate. However, the relationships were not statistically significant (Table 4).

Biodiversity of agrophytocenoses was the lowest in the first study year. The longer the continuous cropping lasted, the greater biodiversity was observed, the maximum value being recorded in the fourth year and the fifth year of continuous cropping. In the sixth and seventh study year, the values of all indices decreased but the values were still higher than in the rotation-based cultivation in the first study year (Table 5). The relationships were not statistically significant, however.

\section{Discussion}

A total of 33 weedy species were found in the experimental plots during the study period. Nikolić et al. (2013) observed a similar number of weedy species (31) in potato which had been grown conventionally. The results reported in this paper indicated that the weed flora communities accompanying potato were significantly impoverished. The segetal community in the untreated plots included 24 species, on average. As metribuzin rate was increased, the floristic abundance declined to a level of 16 species (Table 1). Other authors have reported inconsistent findings. According to Rychcik (2006), the application of herbicides in maize cultivated in continuous cropping resulted in a decrease in the number of weed species from 26 to 20. Jędruszczak and Antoszek (2004) as well as Adamiak et al. (2011) found that the diversity of weed communities decreased in herbicide-treated winter wheat. By contrast, Stupnicka-Rodzynkiewicz et al. (2004) have claimed that herbicides applied in winter wheat and spring barley limited weed numbers but not their diversity. Jastrzębska et al. (2007) have reported that there was no effect of weed control methods on the biodiversity of weed communities in faba bean.

Many authors indicated that application of herbicides reduces the weed density (Stupnicka-Rodzynkiewicz et al. 2004; Rychcik 2006; Pawlonka and Ługowska 2010), which was also confirmed in the study reported here. The weed density consistently decreased as the metribuzin rate was increased (Table 2 ).

Cultivation in continuous cropping influenced both the total species richness and the total weed density in the community. Continuous cultivation of crops, besides an unfavourable impact on the crop plant, had a beneficial influence on the weed flora diversity. Unfortunatelly, it also increased the weed density (Table 2), which is in agreement with the results reported by Rychcik (2006), Kwiatkowski et al. (2004), and Pawlonka (2008). 
Table 1. Species composition and number of weeds (plants $\cdot \mathrm{m}^{-2}$ ) in potato depending on the metribuzin rate (the means for the years 2003-2009)

\begin{tabular}{|c|c|c|c|c|c|}
\hline \multirow{2}{*}{ Weed species } & \multicolumn{5}{|c|}{ Metribuzin rate $\left[\mathrm{kg} \cdot \mathrm{ha}^{-1}\right]$} \\
\hline & 0 (the control) & 0.5 & 1.0 & 1.5 & 2.25 \\
\hline Echinochloa crus-galli (L.) P. Beauv. & 33.1 & 36.4 & 22.6 & 19.0 & 4.5 \\
\hline Chenopodium album $\mathrm{L}$. & 18.8 & 0.6 & 2.4 & 0.1 & 0.0 \\
\hline Matricaria maritima subsp. inodora (L.) Dostal & 8.9 & 4.5 & 3.5 & 0.3 & 0.7 \\
\hline Equisetum arvense $\mathrm{L}$. & 7.3 & 4.6 & 7.6 & 4.9 & 3.5 \\
\hline Galinsoga quadriradiata Ruiz \& Pav. & 0.0 & 6.7 & 0.1 & 0.7 & 0.0 \\
\hline Elymus repens (L.) Gould & 3.7 & 2.1 & 0.9 & 0.4 & 1.0 \\
\hline Fallopia convolvulus (L.) A. Lowe & 1.8 & 0.7 & 0.4 & 0.1 & 0.6 \\
\hline Anchusa arvensis (L.) M. Bieb. & 1.5 & 0.1 & 0.2 & 0.0 & 0.2 \\
\hline Plantago major L. S. Str. & 1.1 & 0.0 & 0.1 & 0.0 & 0.0 \\
\hline Conyza canadensis (L.) Cronquist & 0.7 & 3.6 & 0.6 & 2.8 & 2.0 \\
\hline Setaria pumila (Poir.) Roem \& Schult. & 0.6 & 0.1 & 0.0 & 0.3 & 0.0 \\
\hline Raphanus raphanistrum $\mathrm{L}$. & 0.6 & 0.0 & 0.0 & 0.0 & 0.0 \\
\hline Galinsoga parviflora Cav. & 0.6 & 0.3 & 0.7 & 0.0 & 0.0 \\
\hline Viola arvensis Murray & 0.4 & 1.0 & 0.5 & 0.1 & 0.1 \\
\hline Taraxacum officinale F. H. Wigg. & 0.4 & 0.3 & 0.4 & 0.1 & 0.3 \\
\hline Gnaphalium uliginosum L. & 0.3 & 1.3 & 1.1 & 0.9 & 0.3 \\
\hline Polygonum lapathifolium L. subsp. lapathifolium & 0.3 & 0.0 & 0.0 & 0.0 & 0.0 \\
\hline Bromus secalinus L. & 0.21 & 0.0 & 0.0 & 0.0 & 0.0 \\
\hline Chenopodium polyspermum L. & 0.07 & 0.0 & 0.0 & 0.0 & 0.0 \\
\hline Plantago intermedia Gilib. & 0.07 & 0.0 & 0.0 & 0.0 & 0.0 \\
\hline Sonchus asper (L.) Hill & 0.07 & 0.0 & 0.0 & 0.07 & 0.0 \\
\hline Myosotis arvensis (L.) Hill & 0.07 & 0.0 & 0.0 & 0.07 & 0.0 \\
\hline Artemisia vulgaris L. & 0.07 & 0.04 & 0.0 & 0.0 & 0.0 \\
\hline Galeopsis tetrahit L. & 0.04 & 0.0 & 0.0 & 0.0 & 0.01 \\
\hline Senecio vulgaris $\mathrm{L}$. & 0.0 & 2.6 & 6.1 & 2.5 & 8.7 \\
\hline Galium aparine $\mathrm{L}$. & 0.0 & 1.2 & 1.0 & 0.6 & 5.6 \\
\hline Juncus bufonius L. & 0.0 & 0.0 & 0.0 & 2.1 & 0.0 \\
\hline Cirsium arvense (L.) Scop. & 0.0 & 0.0 & 0.0 & 0.07 & 0.0 \\
\hline Convolvulus arvensis $\mathrm{L}$. & 0.0 & 0.0 & 0.04 & 0.0 & 0.46 \\
\hline Stellaria media (L.) Vill. & 0.0 & 0.0 & 0.0 & 0.0 & 0.07 \\
\hline Capsella bursa-pastoris (L.) Medik. & - & 0.0 & 0.1 & 0.1 & 0.2 \\
\hline Rumex acetosella $\mathrm{L}$. & 0.0 & 0.0 & 0.0 & 0.07 & 0.0 \\
\hline Vicia sativa subsp. nigra (L.) Ehrh. & 0.0 & 0.0 & 0.0 & 0.0 & 0.04 \\
\hline Total number of weeds & $87.4 \mathrm{~d}$ & $59.7 \mathrm{c}$ & $48.9 \mathrm{bc}$ & $34.7 \mathrm{ab}$ & $28.1 \mathrm{a}$ \\
\hline Total number of species & 24.0 & 18.0 & 18.0 & 19.0 & 16.0 \\
\hline The mean number of species & $5.6 \mathrm{c}$ & $4.3 \mathrm{~b}$ & $4.8 \mathrm{bc}$ & $3.3 \mathrm{a}$ & $5.0 \mathrm{bc}$ \\
\hline
\end{tabular}

$a, b, c-$ the means in rows followed by the same letters do not differ significantly $(p \leq 0.05)$ 
Table 2. Species composition and number of weeds (plants $\cdot \mathrm{m}^{-2}$ ) in non-treated (the control plots - without herbicide) potato over the study years

\begin{tabular}{|c|c|c|c|c|c|c|c|}
\hline \multirow{2}{*}{ Weed species } & \multicolumn{7}{|c|}{ Years } \\
\hline & 2003 & 2004 & 2005 & 2006 & 2007 & 2008 & 2009 \\
\hline Echinochloa crus-galli (L.) P. Beauv. & 25.5 & 27.5 & 69.0 & 14.0 & 19.5 & 34.5 & 42.0 \\
\hline Equisetum arvense $\mathrm{L}$. & 3.0 & 1.0 & 4.0 & 4.0 & 2.5 & 6.5 & 30.0 \\
\hline Chenopodium album $\mathrm{L}$. & 2.5 & 2.5 & 57.5 & 20.5 & 10.0 & 38.5 & 0.0 \\
\hline Matricaria maritima subsp. inodora (L.) Dostal & 1.5 & 1.5 & 11.0 & 5.5 & 40.5 & 1.0 & 1.5 \\
\hline Senecio vulgaris L. & 0.0 & 0.0 & 0.0 & 0.0 & 0.0 & 0.0 & 0.0 \\
\hline Gnaphalium uliginosum L. & 0.0 & 0.0 & 0.0 & 0.0 & 2.0 & 0.0 & 0.0 \\
\hline Elymus repens (L.) Gould & 10.0 & 1.0 & 10.0 & 0.0 & 0.0 & 2.5 & 2.5 \\
\hline Galinsoga quadriradiata Ruiz \& Pav. & 46.0 & 0.0 & 0.0 & 0.0 & 0.0 & 0.5 & 0.5 \\
\hline Galium aparine L. & 0.0 & 0.0 & 0.0 & 0.0 & 0.0 & 0.0 & 0.0 \\
\hline Fallopia convolvulus (L.) A. Lowe & 2.0 & 1.0 & 6.5 & 1.0 & 2.0 & 0.0 & 0.0 \\
\hline Conyza canadensis (L.) Cronquist & 0.0 & 0.0 & 0.0 & 0.0 & 5.0 & 0.0 & 0.0 \\
\hline Setaria pumila (Poir.) Roem \& Schult. & 1.0 & 0.0 & 0.0 & 0.5 & 1.5 & 1.0 & 0.0 \\
\hline Anchusa arvensis (L.) M. Bieb. & 0.5 & 0.0 & 3.0 & 5.5 & 0.5 & 1.0 & 0.0 \\
\hline Viola arvensis Murray & 0.5 & 2.5 & 0.0 & 0.0 & 0.0 & 0.0 & 0.0 \\
\hline Raphanus raphanistrum $\mathrm{L}$. & 0.0 & 0.0 & 2.0 & 0.0 & 1.0 & 1.0 & 0.0 \\
\hline Juncus bufonius L. & 0.0 & 0.0 & 0.0 & 0.0 & 0.0 & 0.0 & 0.0 \\
\hline Galinsoga parviflora Cav. & 0.0 & 0.0 & 0.0 & 0.5 & 0.0 & 3.5 & 0.5 \\
\hline Plantago major L.S. Str. & 0.0 & 2.0 & 4.0 & 0.0 & 0.5 & 1.0 & 0.0 \\
\hline Taraxacum officinale F.H. Wigg. & 0.0 & 0.0 & 0.0 & 0.0 & 0.5 & 0.0 & 2.0 \\
\hline Cirsium arvense (L.) Scop. & 0.0 & 0.0 & 0.0 & 0.0 & 0.0 & 0.0 & 0.0 \\
\hline Convolvulus arvensis L. & 0.0 & 0.0 & 0.0 & 0.0 & 0.0 & 0.0 & 0.0 \\
\hline Stellaria media (L.) Vill. & 0.0 & 0.0 & 0.0 & 0.0 & 0.0 & 0.0 & 0.0 \\
\hline Polygonum lapathifolium L. subsp. lapathifolium & 0.0 & 0.0 & 0.5 & 0.5 & 0.0 & 0.0 & 1.0 \\
\hline Bromus secalinus L. & 0.0 & 0.0 & 0.0 & 0.0 & 0.0 & 0.0 & 1.5 \\
\hline Capsella bursa-pastoris (L.) Medik. & 0.0 & 0.0 & 0.0 & 0.0 & 0.0 & 0.0 & 0.0 \\
\hline Chenopodium polyspermum L. & 0.0 & 0.5 & 0.0 & 0.0 & 0.0 & 0.0 & 0.0 \\
\hline Plantago intermedia Gilib. & 0.0 & 0.5 & 0.0 & 0.0 & 0.0 & 0.0 & 0.0 \\
\hline Sonchus asper (L.) Hill & 0.0 & 0.0 & 0.0 & 0.0 & 0.5 & 0.0 & 0.0 \\
\hline Myosotis arvensis (L.) Hill & 0.0 & 0.0 & 0.0 & 0.0 & 0.5 & 0.0 & 0.0 \\
\hline Rumex acetosella $\mathrm{L}$. & 0.0 & 0.0 & 0.0 & 0.0 & 0.0 & 0.0 & 0.0 \\
\hline Artemisia vulgaris L. & 0.0 & 0.0 & 0.0 & 0.0 & 0.5 & 0.0 & 0.0 \\
\hline Vicia sativa subsp. nigra (L.) Ehrh. & 0.0 & 0.0 & 0.0 & 0.0 & 0.0 & 0.0 & 0.0 \\
\hline Galeopsis tetrahit L. & 0.0 & 0.0 & 0.0 & 0.0 & 0.0 & 0.0 & 0.0 \\
\hline Total number of weeds & $46.5 \mathrm{a}$ & $40.0 \mathrm{a}$ & $167.5 \mathrm{c}$ & $52.0 \mathrm{a}$ & $88.0 \mathrm{ab}$ & $90.5 \mathrm{ab}$ & $127.0 \mathrm{bc}$ \\
\hline Total number of species & 9.0 & 10.0 & 10.0 & 9.0 & 16.0 & 11.0 & 9.0 \\
\hline The mean number of species & $5.5 \mathrm{ab}$ & $4.3 \mathrm{a}$ & $5.8 \mathrm{ab}$ & $4.3 \mathrm{a}$ & $7.5 \mathrm{~b}$ & $6.5 \mathrm{ab}$ & $5.5 \mathrm{ab}$ \\
\hline
\end{tabular}

$\mathrm{a}, \mathrm{b}, \mathrm{c}-$ the means in rows followed by the same letters do not differ significantly $(\mathrm{p} \leq 0.05)$ 
Table 3. Infestation of potato with Echinochloa crus-galli depending on the metribuzin rate in successive years of monoculture

\begin{tabular}{|c|c|c|c|c|c|c|}
\hline \multirow{2}{*}{ Years } & \multicolumn{6}{|c|}{ Metribuzin rate $\left[\mathrm{kg} \cdot \mathrm{ha}^{-1}\right]$} \\
\hline & 0 (the control) & 0.5 & 1.0 & 1.5 & 2.25 & the mean \\
\hline 2003 & 25.5 & 24.0 & 16.0 & 14.5 & 2.25 & $16.5 \mathrm{a}$ \\
\hline 2004 & 27.5 & 21.5 & 9.0 & 8.0 & 9.0 & $15.0 \mathrm{a}$ \\
\hline 2005 & 69.0 & 80.0 & 50.0 & 23.0 & 3.0 & $45.0 \mathrm{~b}$ \\
\hline 2006 & 14.0 & 21.5 & 30.0 & 29.5 & 4.0 & $19.8 \mathrm{a}$ \\
\hline 2007 & 19.5 & 12.0 & 5.0 & 3.5 & 5.5 & $9.1 \mathrm{a}$ \\
\hline 2008 & 34.5 & 40.5 & 13.5 & 14.0 & 2.8 & $21.1 \mathrm{a}$ \\
\hline 2009 & 42.0 & 55.0 & 34.5 & 40.5 & 5.0 & $35.4 \mathrm{~b}$ \\
\hline The mean & $33.1 \mathrm{~cd}$ & $36.4 \mathrm{~d}$ & $22.6 \mathrm{bc}$ & $19.0 \mathrm{~b}$ & $4.5 \mathrm{a}$ & 23.1 \\
\hline
\end{tabular}

$\mathrm{a}, \mathrm{b}, \mathrm{c}, \mathrm{d}$ - the means in rows followed by the same letters do not differ significantly $(\mathrm{p} \leq 0.05)$

Table 4. Shannon-Wiener index of biodiversity $\left(H^{\prime}\right)$, Simpson's index of biodiversity $(C)$ and Simpson's index of domination $(D)$ in potato, depending on the metribuzin rate (the means for the years 2003-2009)

\begin{tabular}{cccccc}
\hline \multirow{2}{*}{ Index } & \multicolumn{5}{c}{ Metribuzin rate $\left[\mathrm{kg} \cdot \mathrm{ha}^{-1}\right]$} \\
\cline { 2 - 6 } & 0 (the control) & 0.5 & 1.0 & 1.5 & 2.25 \\
\hline$H^{\prime}$ & $1.95 \mathrm{a}$ & $1.54 \mathrm{a}$ & $1.83 \mathrm{a}$ & $1.60 \mathrm{a}$ & $1.97 \mathrm{a}$ \\
$C$ & $0.78 \mathrm{a}$ & $0.60 \mathrm{a}$ & $0.73 \mathrm{a}$ & $0.66 \mathrm{a}$ & $0.81 \mathrm{a}$ \\
$D$ & $0.21 \mathrm{a}$ & $0.39 \mathrm{a}$ & $0.26 \mathrm{a}$ & $0.33 \mathrm{a}$ & $0.18 \mathrm{a}$ \\
\hline
\end{tabular}

a - the means followed by the same letters do not differ significantly $(\mathrm{p} \leq 0.05)$

Table 5. Shannon-Wiener index of biodiversity $\left(H^{\prime}\right)$, Simpson's index of biodiversity $(C)$, and Simpson's index of domination $(D)$ in potato cultivated in the successive study years (averaged over the metribuzin rates)

\begin{tabular}{ccccccccc}
\hline \multirow{2}{*}{ Index } & \multicolumn{7}{c}{ Years } \\
\cline { 2 - 9 } & 2003 & 2004 & 2005 & 2006 & 2007 & 2008 & 2009 \\
\hline$H^{\prime}$ & $1.32 \mathrm{a}$ & $1.73 \mathrm{a}$ & $1.75 \mathrm{a}$ & $2.18 \mathrm{a}$ & $2.20 \mathrm{a}$ & $1.66 \mathrm{a}$ & $1.56 \mathrm{a}$ \\
$C$ & $0.52 \mathrm{a}$ & $0.68 \mathrm{a}$ & $0.71 \mathrm{a}$ & $0.82 \mathrm{a}$ & $0.85 \mathrm{a}$ & $0.73 \mathrm{a}$ & $0.68 \mathrm{a}$ \\
$D$ & $0.47 \mathrm{a}$ & $0.31 \mathrm{a}$ & $0.28 \mathrm{a}$ & $0.17 \mathrm{a}$ & $0.14 \mathrm{a}$ & $0.26 \mathrm{a}$ & $0.31 \mathrm{a}$ \\
\hline
\end{tabular}

$\mathrm{a}$ - the means followed by the same letters do not differ significantly $(\mathrm{p} \leq 0.05)$

Table 6. Sielianinow's thermal coefficient

\begin{tabular}{cccccc}
\hline \multirow{2}{*}{ Year } & \multicolumn{3}{c}{ Month } \\
\cline { 2 - 5 } & April & May & June & July & August \\
\hline 2003 & 0.64 & 0.77 & 0.48 & 0.42 & 0.08 \\
2004 & 1.49 & 2.70 & 1.14 & 0.90 & 1.14 \\
2005 & 0.47 & 1.60 & 0.92 & 1.38 & 0.84 \\
2006 & 1.18 & 0.94 & 0.46 & 0.23 & 4.08 \\
2007 & 0.82 & 1.30 & 1.08 & 1.20 & 0.53 \\
2008 & 1.03 & 2.17 & 0.94 & 1.22 & 1.99 \\
2009 & 0.26 & 1.72 & 3.08 & 0.44 & 1.47 \\
\hline
\end{tabular}

The largest total number of weeds was observed in the control plots in 2005, and the greatest species richness per community in 2007. Sielianinow's coefficient values were calculated to find out if there was an effect of weather conditions (Table 6). The coeeficient is computed as a ratio of the precipitation sum over a given period and the 0.1 temperature sum for this period (Hutorowicz et al. 2008). The years 2005 and 2007 had favourable weather conditions in May when plants received an optimum amount of rainfall. Moreover, the weather in June and July was also good.

The indices of biodiversity partially confirmed the trends discussed above. The biodiversity of agrophytocenosis declined after an application of the herbicide with an exception of the plots where the highest metribuzin rate had been applied (Table 4). 
Indices of biodiversity calculated for successive years of continuous potato cultivation may indicate that short-term continuous cropping not only does not disturb the agrophytocenosis but also increases its biodiversity and reduces species domination (Table 5). However, other authors have reported different findings. According to Stupnicka-Rodzynkiewicz et al. (2004), the effect of rotation on the diversity of weed species is insignificant. But Jędruszczak and Antoszek (2004) claimed that as continuous cropping progresses, the index of domination increases and the index of overall diversity decreases.

The similarity of biodiversity indices, and the number of weed species and their abundance, reported by Anyszka and Kohut (2011) for weed communities in vegetables, was only partially confirmed in this work.

\section{References}

Adamiak E., Adamiak J. 2004. Zachwaszczenie owsa w warunkach zróżnicowanego następstwa roślin i chemicznej ochrony łanu. [Effect of varied crop sequence and chemical control of the stand on weed infestation of oat]. Acta Scientiarum Polonorum. Agricultura 3 (1): 119-128. (in Polish with English summary)

Adamiak E., Adamiak J., Przybylski R. 2011. Znaczenie płodozmianu w regulacji zachwaszczenia zbóż ozimych. [Significance of crop rotation on the regulation weed infestation in winter cereales]. Progress in Plant Protection/ Postępy w Ochronie Roślin 51 (2): 817-821. (in Polish with English summary)

Anyszka Z., Kohut M. 2011. Bioróżnorodność zbiorowisk chwastów segetalnych w uprawach wybranych gatunków warzyw. [Biodiversity of segetal weed communities in cultivations of selected vegetable crops]. Progress in Plant Protection/Postępy w Ochronie Roślin 51 (3): 1219-1223. (in Polish with English summary)

Hutorowicz H., Grabowski J., Olba-Zięty E. 2008. Częstotliwość występowania okresów posusznych i suchych w dwóch mezoregionach Pojezierza Mazurskiego. [Frequency of occurrence of dry spells and droughts in two mesoregions of Masurian Lakeland]. Acta Agrophysica 12 (3): 663-673. (in Polish)

Jastrzębska M., Bogucka B., Hruszka M. 2007. Następstwo roślin i proekologiczne sposoby regulacji zachwaszczenia a bioróżnorodność chwastów w bobiku. [Crop sequence and environment-friendly weed control methods versus weed biodiversity in faba bean fields]. Acta Agrophysica 10 (2): 357-371. (in Polish)

Jędruszczak M., Antoszek R. 2004. Sposoby uprawy roli a bioróżnorodność zbiorowisk chwastów w monokulturze pszenicy ozimej. [Tillage systems and biodiversity of weed communities in winter wheat monoculture]. Acta Scientiarum Polonorum. Agricultura 3 (2): 47-59. (in Polish with English summary)

KwiatkowskiC.2009. Struktura zachwaszczeniai produktywność biomasy pszenicy ozimej oraz chwastów w zależności od systemu następstwa roślin i sposobu pielęgnacji. [Weed infestation structure and biomass productivity of winter wheat and weeds depending on crop sequence system and protection method]. Annales UMCS, Sectio E, 64 (3): 69-78. (in Polish)
Kwiatkowski C., Wesołowski M., Stępień A. 2004. Bioróżnorodność chwastów w trzech odmianach jęczmienia jarego uprawianych w siedmioletniej monokulturze i zmianowaniu. [Biodiversity of weeds in three cultivars of spring barley grown in seven-year monoculture and crop rotation]. Acta Scientiarum Polonorum. Agricultura 3 (2): 109-117. (in Polish with English summary)

Ługowska M., Rzymowska Z. 2014. The effect of the application of the exact and approximate methods on values of selected ecological indices. Acta Agrobotanica 67 (1):39-46.

Mirek Z., Piękoś-Mirkowa H., Zając A., Zając M. 2002. Flowering plants and pteridophytes of Poland - a checklist. Vol. 1 . Biodiversity of Poland. W. Szafer Institute of Botany, Polish Academy of Sciences, Cracow, Poland, $442 \mathrm{pp}$.

Nikolić L., Ilić O., Dzigurski D., Ljevnaić-Masić B. 2013. Analysis of weed flora in conventional and organic potato production. Biologica Nyssana 4 (1-2): 9-14.

Pawlonka Z. 2008. Plonowanie jęczmienia jarego w monokulturze przy różnym poziomie ochrony chemicznej przed chwastami. [Spring barley yield in monoculture under differentiated intensity of weed control]. Progress in Plant Protection/Postępy w Ochronie Roślin 48 (1): 307-312. (in Polish with English summary)

Pawlonka Z., Ługowska M. 2010. Plonowanie pszenicy ozimej w monokulturze przy różnym poziomie ochrony chemicznej przed chwastami. [Winter wheat yield in monoculture under differentiated intensity of weed control]. Progress in Plant Protection/Postępy w Ochronie Roślin 50 (2): 823827. (in Polish with English summary)

Rychcik B. 2006. Wpływ herbicydów i następstwa roślin na zachwaszczenie kukurydzy (Zea mays L.). [Effect of herbicides and crop sequence on weed infestation of maize (Zea mays L.)]. Progress in Plant Protection/Postępy w Ochronie Roślin 46 (2): 170-173. (in Polish with English summary)

Rzymowska Z., Ługowska M., Skrzyczyńska J. 2013. Species diversity of segetal communities in tuber crops and in winter and spring cereals. Acta Agrobotanica 66 (3): 95-102.

Shannon C.E. 1948. A mathematical theory of communication. Bell System Technical Journal 27: 379-423, 623-656.

Simpson E.H. 1949. Measurement of diversity. Nature 163: 688.

Skrzyczyńska J., Ługowska M. 2008. Dominacja gatunków i bioróżnorodność zbiorowisk agrocenoz ziemniaka Doliny Środkowej Wisły. [Species domination and biodiversity in weed communities of agrocenoses of the middle vistula valley]. Zeszyty Problemowe Postępów Nauk Rolniczych 530: 105-115. (in Polish)

Stupnicka-Rodzynkiewicz E., Stępnik K., Lepiarczyk A. 2004. Wpływ zmianowania, sposobu uprawy roli i herbicydów na bioróżnorodność zbiorowisk chwastów. [Effect of the crop rotation, tillage method and herbicides on the biodiversity of weed communities]. Acta Scientiarum Polonorum. Agricultura 3 (2): 235-245. (in Polish with English summary)

Trętowski J., Wójcik A.R., 1992. Metodyka doświadczeń rolniczych. [Methodology of agricultural experiments]. WSRP, Siedlce, 583 pp. (in Polish)

Wilson E. 1988. Biodiversity. National Academy Press, Washington DC, $521 \mathrm{pp}$. 